\title{
Acanthosis Nigricans dan Hubungannya dengan Resistensi Insulin pada Anak dan Remaja
}

\author{
Jose RL Batubara
}

Departemen Ilmu Kesehatan Anak, RS Dr Cipto Mangunkusumo, Fakultas Kedokteran Universitas Indonesia, Jakarta

\begin{abstract}
Acanthosis nigricans (AN) bukan hanya sekedar kelainan kulit saja, tetapi dipandang sebagai petanda adanya penyakit lain yang mendasari, salah satunya adalah resistensi insulin. Prevalensi AN bervariasi dari 7\% pada populasi umum sampai dengan $74 \%$ pada orang dengan obesitas. Penelitian terakhir memperlihatkan bahwa derajat beratnya AN berhubungan dengan konsentrasi insulin plasma puasa dan indeks masa tubuh (IMT). Tidak ada perbedaan insidens antara laki-laki dan perempuan. Secara garis besar AN dibagi menjadi dua kategori besar yaitu jinak (benign) dan ganas (malignant). Acanthosis nigricans pada sindrom resistensi insulin disebabkan karena kadar insulin yang tinggi mampu mengaktifkan fibroblas dermal dan keratinosit melalui reseptor insulin-like growth factor yang ada pada sel-sel tersebut. Sebagai hasilnya terjadi peningkatan deposisi glikosaminoglikans oleh fibroblas di dermal. Hal ini menyebabkan papilomatosis dan hiperkeratosis. Acanthosis nigricans dilaporkan sebagai salah satu faktor prediktor hiperinsulinemia yang cukup baik. Skrining adanya AN merupakan alat yang cukup sederhana, cepat, mudah, dan murah untuk mendeteksi individu yang berisiko menderita diabetes tipe 2 dan penyakit lain yang berhubungan dengan hiperinsulinemia. Skrining AN di klinik dan sekolah untuk mengidentifikasi individu yang berisiko tinggi menderita diabetes tipe 2 memiliki implikasi penting dalam pengembangan strategi intervensi melawan $\mathrm{DM}$, terutama di tingkat layanan primer. Tujuan terapi pada AN adalah untuk mengkoreksi penyakit yang mendasarinya. Koreksi hiperinsulinemia dapat mengurangi derajat lesi hiperkeratosis, begitu juga dengan penurunan berat badan. (Sari Pediatri 2010;12(2):67-73).
\end{abstract}

Kata kunci: Acanthosis nigricans, resistensi insulin, hiperinsulinemia, obesitas, skrining

$A$ canthosis nigricans (AN) adalah suatu kelainan kulit berupa penebalan dan kehitaman pada kulit yang ditandai dengan papilomatosis dan plak hiperkeratosis, terutama pada daerah leher dan lipatan kulit. ${ }^{1}$ Acanthosis nigricans

\footnotetext{
Alamat korespondensi:

Dr. Jose R.L. Batubara, Sp.A(K), PhD. Departemen Ilmu Kesehatan Anak FKUI/RSCM Jl. Salemba 6 Jakarta. Telp/fax 021-3915712
}

tidak hanya dianggap sebagai kelainan kulit saja, tetapi sering dipandang sebagai petanda adanya penyakit lain yang mendasari. Acanthosis nigricans pertama kali dikemukakan pada tahun 1889, namun baru pada tahun 1976 Kahn $\mathrm{dkk}^{2}$ mempublikasikan penelitian mengenai hubungan antara AN dengan resistensi insulin.

Acanthosis nigricans sering dihubungkan dengan obesitas, kelainan endokrin, keganasan, sindrom tertentu, dan penggunaan beberapa obat. Hiperinsulinemia merupakan kondisi yang paling banyak dihubungkan 
dengan AN. Kondisi metabolik lain yang berhubungan dengan AN antara lain obesitas, diabetes mellitus, toleransi glukosa terganggu, dislipidemia, ovarium polikistik, hipertensi, hiperprolaktinemia, hipertiroid, hipotiroid, dan penyakit Addison. ${ }^{1-8}$

Insidens diabetes mellitus tipe 2 terus meningkat sehingga dibutuhkan intervensi lebih dini berupa pencegahan. Didapatkan bahwa intervensi berupa perubahan gaya hidup dapat mencegah atau memperlambat timbulnya diabetes mellitus tipe 2 sebanyak $58 \% .{ }^{1}$ Oleh karena itu, sangatlah penting untuk mengidentifikasi pasien yang memiliki risiko tinggi diabetes sebelum penyakit ini tampak secara klinis. Selama ini identifikasi pasien dengan risiko tinggi dilakukan dengan identifikasi faktor risiko yang telah diketahui seperti riwayat keluarga diabetes, overweight atau obesitas, dan etnis tertentu. Namun cara ini sering tidak efektif dalam populasi yang memiliki prevalensi yang tinggi faktor-faktor tersebut.

Berbagai penelitian telah menyatakan adanya hubungan antara AN dengan hiperinsulinemia. Hubungan antara AN dengan hiperinsulinemia inilah yang kemudian menempatkan AN sebagai sarana skrining pasien yang membutuhkan intervensi dini berupa modifikasi gaya hidup. Diharapkan dengan metode ini, intervensi dapat diberikan sedini mungkin sebelum diabetes mellitus berkembang.

\section{Epidemiologi}

Insidens AN sampai saat ini belum diketahui secara pasti. Di Amerika Serikat, AN ditemukan pada 7,1\% dari 1412 anak. $^{3}$ Prevalensi AN bervariasi dari $7 \%$ pada populasi umum sampai dengan $74 \%$ pada orang dewasa dengan obesitas. ${ }^{7}$ Penelitian terakhir memperlihatkan bahwa derajat beratnya AN berhubungan dengan konsentrasi insulin plasma puasa dan indeks masa tubuh (IMT). Acanthosis nigricans lebih sering dijumpai pada orang berkulit gelap dengan prevalensi pada kulit putih $<1 \%$, sedangkan pada kulit hitam 13,3\%. Tidak ada perbedaan insidens antara laki-laki dan perempuan. Acanthosis nigricans dapat timbul pada semua usia, meskipun lebih sering ditemukan pada populasi dewasa. ${ }^{3}$

\section{Klasifikasi}

Secara garis besar AN dibagi menjadi dua kategori besar yaitu bentuk jinak (benign) dan bentuk ganas (malignant). Bentuk yang jinak berhubungan dengan

Tabel 1. Klasifikasi acanthosis nigricans ${ }^{3,9}$

\begin{tabular}{|c|c|}
\hline $\begin{array}{l}\text { Pseudo acanthosis nigricans/ } \\
\text { obesity associated acanthosis } \\
\text { nigricans }\end{array}$ & $\begin{array}{l}\text { Dipengaruhi oleh berat badan dan lesi dapat hilang sempurna dengan } \\
\text { penurunan berat badan. Dapat timbul pada semua umur tetapi paling } \\
\text { sering dijumpai pada dewasa. }\end{array}$ \\
\hline Syndromic acanthosis nigricans & $\begin{array}{l}\text { AN yang berhubungan dengan sindrom, misalnya ovarium polikistik } \\
\text { atau penyakit autoimun seperti SLE, skleroderma, dan tiroiditis } \\
\text { Hashimoto. }\end{array}$ \\
\hline $\begin{array}{l}\text { Acanthosis nigricans akral (acral } \\
A N)\end{array}$ & $\begin{array}{l}\text { Timbul pada pasien yang sehat, paling sering pada individu berkulit } \\
\text { gelap. Lesi terutama pada dorsal tangan dan kaki. }\end{array}$ \\
\hline Acanthosis nigricans unilateral & $\begin{array}{l}\text { Diturunkan secara autosomal dominan. Lesi bersifat unilateral, lesi akan } \\
\text { membesar dahulu sebelum akhirnya mengecil atau menetap. }\end{array}$ \\
\hline Acanthosis nigricans familial & $\begin{array}{l}\text { Diturunkan secara autosomal dominan, pada umumnya terjadi selama } \\
\text { masa kanak-kanak. }\end{array}$ \\
\hline $\begin{array}{l}\text { Acanthosis nigricans yang } \\
\text { diinduksi oleh obat }\end{array}$ & $\begin{array}{l}\text { Jarang terjadi, diinduksi oleh beberapa obat termasuk asam nikotinik, } \\
\text { insulin, kortikosteroid, dan dietilstilbestrol. Lesi AN mengalami regresi } \\
\text { setelah penghentian obat. }\end{array}$ \\
\hline Acanthosis nigricans maligna & $\begin{array}{l}\text { Berhubungan dengan keganasan, terutama adenokarsinoma } \\
\text { gastrointestinal. }\end{array}$ \\
\hline $\begin{array}{l}\text { Acanthosis nigricans tipe } \\
\text { campuran }\end{array}$ & $\begin{array}{l}\text { Timbul lesi AN jenis yang berbeda pada pasien yang sudah memiliki } \\
\text { salah satu jenis AN }\end{array}$ \\
\hline
\end{tabular}


resistensi insulin, bervariasi dari ringan sampai diabetes mellitus. Sedangkan acanthosis nigricans bentuk ganas pada umumnya berhubungan dengan berbagai komplikasi yang berhubungan dengan keganasan yang mendasarinya. Lebih lanjut AN dapat diklasifikasikan menjadi delapan tipe seperti tertera pada Tabel 1. ${ }^{9}$

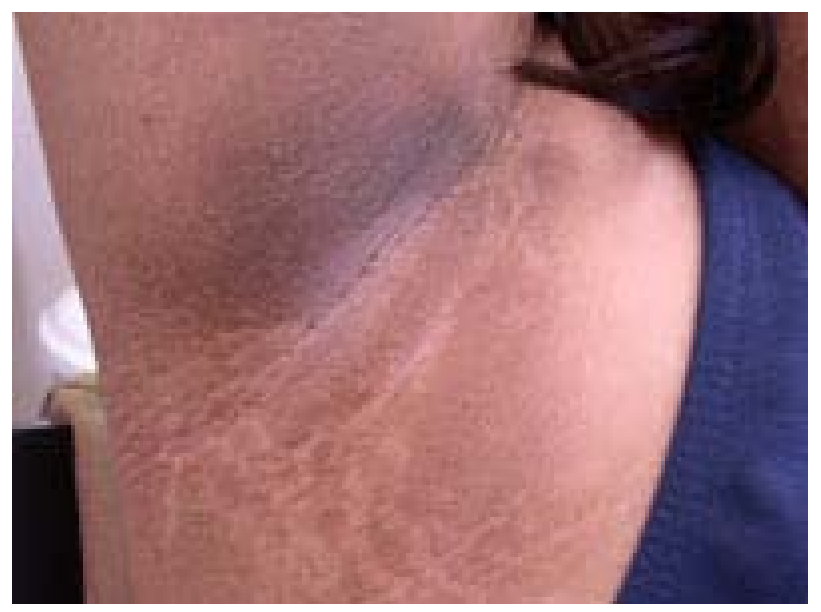

Gambar 1. Acanthosis nigricans pada ketiak

\section{Manifestasi klinis}

Acanthosis nigricans ditandai oleh lesi kulit hiperpigmentasi, tebal, dan berlapis-lapis (Gambar 1). Lesi dapat timbul pada berbagai tempat di tubuh, terutama daerah lipatan seperti bagian belakang leher, ketiak, inguinal, siku, dan di bawah payudara. Papilomatosis sering ditemukan pada permukaan kulit dan mukosa. Terkadang ditemukan skin tag pada lesi AN atau kulit di sekitarnya. Dapat disertai gatal. Acanthosis nigricans terkadang dapat timbul pada membran mukosa mulut, nasal, dan esofagus serta dapat mengenai konjungtiva dan kelopak mata. Perubahan kuku seperti hiperkeratosis dan leukokonikia juga pernah dilaporkan. Manifestasi klinis AN maligna sulit dibedakan dengan AN benigna, akan tetapi AN maligna biasanya timbul pada pasien tengah baya, tidak gemuk dan lesinya timbul secara mendadak.,

Burke $\mathrm{dkk}^{10}$ membuat skala kuantitatif untuk menyatakan derajat AN. Skala ini dibuat berdasarkan derajat beratnya penyakit berdasarkan lokasi AN yaitu pada daerah aksila, leher, siku, lutut, dan ruas sendisendi jari (Tabel 2).

Tabel 2. Skala kuantitatif derajat acanthosis nigricans

\begin{tabular}{|c|c|c|}
\hline Lokasi & Nilai & Deskripsi \\
\hline \multirow{5}{*}{ Leher } & 0 & Tak terlihat dengan inspeksi jarak dekat \\
\hline & 1 & $\begin{array}{l}\text { Jelas tampak dengan inspeksi jarak dekat, tidak tampak oleh pengamat awam, batas } \\
\text { tidak dapat diukur }\end{array}$ \\
\hline & 2 & $\begin{array}{l}\text { Ringan: terbatas pada leher dan tidak melebar ke batas tepi leher, biasanya } \\
\text { diameternya }<3 \text { inci }\end{array}$ \\
\hline & 3 & $\begin{array}{l}\text { Sedang: melebar ke tepi leher (batas posterior m. sternocleidomastoideus), 3-6 inci. } \\
\text { Tidak terlihat dari depan }\end{array}$ \\
\hline & 4 & Berat: melebar ke anterior dan terlihat dari depan, diameter $>6$ inci \\
\hline \multirow[t]{5}{*}{ Aksila } & 0 & Tak terlihat dengan inspeksi jarak dekat \\
\hline & 1 & $\begin{array}{l}\text { Jelas tampak dengan inspeksi jarak dekat, tidak tampak oleh pengamat awam, batas } \\
\text { tidak dapat diukur }\end{array}$ \\
\hline & 2 & Ringan: terlokalisir di sentral aksila, bisa kadang-k adang tidak terlihat \\
\hline & 3 & $\begin{array}{l}\text { Sedang: mengenai seluruh aksila, tapi tak tampak saat lengan penderita menempel } \\
\text { pada sisi badan }\end{array}$ \\
\hline & 4 & $\begin{array}{l}\text { Berat: tampak jelas dari depan atau belakang bila penderita tidak berpakaian dan } \\
\text { lengan penderita menempel pada sisi badan. }\end{array}$ \\
\hline Lutut siku sendi jari & & Tidak ada \\
\hline \multirow[t]{4}{*}{ Tekstur leher } & 0 & Halus saat disentuh: tidak ada perbedaan dengan kulit normal disekitarnya \\
\hline & 1 & Kasar saat disentuh: jelas perbedaannya dengan kulit normal disekitarnya \\
\hline & 2 & Kekasaran kulit jelas terlihat \\
\hline & 3 & Permukaan kulit terlihat lebih tinggi dari sekitarnya \\
\hline
\end{tabular}




\section{Hubungan acanthosis nigricans dengan resistensi insulin}

Penelitian yang meneliti hubungan langsung antara resistensi insulin dan AN pada anak hanya sedikit ditemukan. Namun dari penelitian yang sudah ada, didapatkan bahwa AN berkaitan erat dengan hiperinsulinemia, yang merupakan akibat dari resistensi insulin.

Acanthosis nigricans telah dilaporkan pada beberapa penelitian disebabkan oleh meningkatnya melanosit dan melanin, sedangkan yang lainnya menyatakan bahwa AN lebih berhubungan dengan penebalan lapisan kulit luar yang mengandung keratin. Acanthosis nigricans pada sindrom resistensi insulin disebabkan karena kadar insulin yang tinggi mampu mengaktifkan fibroblas dermal dan keratinosit melalui reseptor insulin-like growth factor yang ada pada sel-sel tersebut. Sebagai hasilnya terjadi peningkatan deposisi glikosaminoglikans oleh fibroblas di dermal. Hal ini menyebabkan papilomatosis dan hiperkeratosis.

Insulin dengan konsentrasi rendah mengatur metabolisme karbohidrat, lipid, dan protein, serta membantu pertumbuhan dengan berikatan pada reseptor insulin. Dalam konsentrasi yang tinggi, insulin memiliki efek lebih besar dalam pertumbuhan melalui ikatannya dengan insulin-like growth factor 1 receptors (IGF-1Rs), yaitu reseptor dengan ukuran dan struktur menyerupai reseptor insulin, tetapi memiliki afinitas 100 sampai 1000 kali lebih besar. Hasil penelitian menyatakan bahwa aktivasi IGF-1 Rs yang bergantung

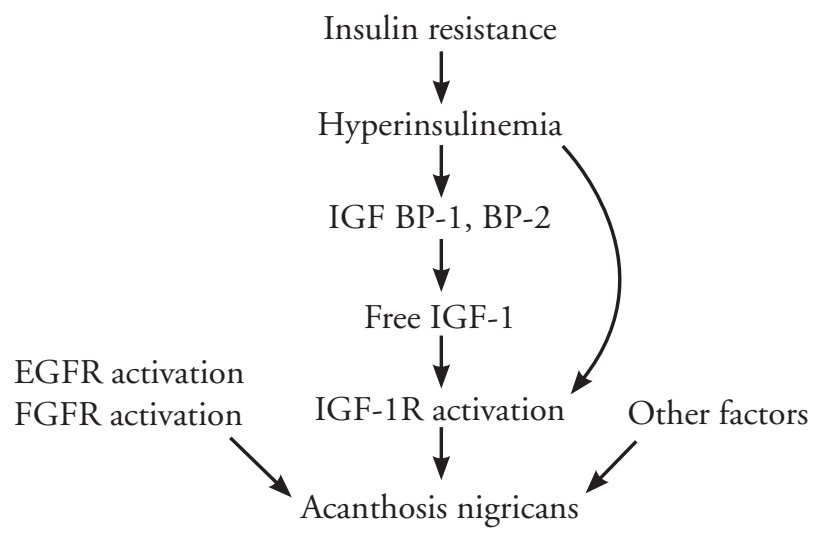

Gambar 2. Patogenesis acanthosis nigricans. ${ }^{12}$ pada insulin dalam menyebabkan proliferasi sel dan memfasilitasi berkembangnya AN. Jadi insulin dapat menyebabkan AN melalui aktivasi langsung jalur sinyal IGF-1. ${ }^{12}$

Hiperinsulinemia juga dapat memfasilitasi berkembang AN secara tidak langsung, yaitu dengan meningkatkan kadar IGF-1 bebas dalam sirkulasi darah. IGF binding protein (IGFBPs) mengatur aktivitas IGF-1, yaitu dengan meningkatkan waktu paruh IGF-1, menghantarkan IGF ke jaringan target, dan mengatur kadar IGF-1 bebas. Insulin-like growth factor binding protein I (IGFBP) jumlahnya menurun pada pasien obese dengan hiperinsulinemia, sehingga meningkatkan konsentrasi plasma dari IGF-1 bebas (Gambar 2). Jumlah IGF-1 yang meningkat menyebabkan bertambahnya pertumbuhan dan diferensiasi sel. ${ }^{12}$

Pada kasus dengan keganasan dan adenoma yang berhubungan dengan AN, peningkatan produksi growth factor, insulin like activity and transforming growth factor- $\alpha$ berperan dalam timbulnya AN. Antibodi terhadap reseptor insulin dapat menjelaskan hubungan AN dengan penyakit autoimun lainnya. ${ }^{3}$

Acanthosis nigricans telah dianggap sebagai salah satu petanda resistensi insulin dan faktor risiko timbulnya diabetes mellitus tipe 2, terutama pada dewasa muda. Anak dengan AN memiliki kemungkinan 1,6 sampai 4,2 kali lebih besar daripada anak yang tidak menderita kelainan yang sama untuk mengalami hiperinsulinemia. ${ }^{13}$ Hubungan inilah yang kemudian menimbulkan pemikiran lebih jauh bahwa AN juga berhubungan dengan diabetes tipe 2. Berdasarkan penelitian yang dilakukan oleh Kong dkk, ${ }^{14}$ didapatkan bahwa prevalensi AN pada penderita diabetes tipe 2 lebih tinggi daripada pada bukan penderita ( $47 \%$ berbanding $17 \%$, dengan $\mathrm{p}<0,001)$. Acanthosis nigricans juga dihubungkan dengan memiliki faktor risiko multipel terhadap diabetes mellitus tipe 2. Prevalensi acanthosis nigricans meningkat sesuai dengan banyaknya faktor risiko yang dimiliki. Stuart dkk memperlihatkan adanya korelasi antara konsentrasi insulin dengan derajat beratnya AN. ${ }^{12-14}$ Burke $\mathrm{dkk}^{10}$ menemukan bahwa derajat beratnya AN berhubungan dengan meningkatnya kadar insulin puasa dan IMT.

Seiring dengan meningkatnya insidens diabetes tipe 2, dibutuhkan suatu metode untuk mendeteksi kelainan secara dini, AN adalah salah satunya. 
Acanthosis nigricans dilaporkan sebagai salah satu faktor prediktor hiperinsulinemia yang handal, sehingga skrining adanya AN merupakan alat yang cukup sederhana, cepat, mudah, dan murah untuk mendeteksi individu yang berisiko menderita diabetes tipe 2 dan penyakit lain yang berhubungan dengan hiperinsulinemia. ${ }^{15}$ Skrining AN di klinik dan sekolah untuk mengidentifikasi individu yang berisiko tinggi menderita diabetes tipe 2 memiliki implikasi penting dalam pengembangan strategi intervensi melawan $\mathrm{DM},{ }^{12}$ terutama di tingkat layanan primer. Deteksi AN dapat menjadi metode yang efektif dalam mengidentifikasi pasien yang membutuhkan intervensi dini berupa modifikasi gaya hidup. ${ }^{14}$ Faktor risiko diabetes lain seperti riwayat keluarga diabetes atau obesitas seringkali tidak banyak berperan dalam memotivasi perubahan perilaku. Tanda fisik yang mudah dikenali, seperti AN, yang dapat memudahkan identifikasi pasien dengan risiko tinggi diabetes melitus tipe 2, dapat menjadi alat skrining yang lebih efektif. ${ }^{13}$ Penelitian Kong dkk ${ }^{14}$ menemukan adanya perubahan perilaku dari pasien dengan AN. Kesadaran akan AN dan hubungannya dengan diabetes tipe 2 telah membuat pasien lebih terbuka terhadap diskusi mengenai perubahan gaya hidup. Namun hubungan perubahan perilaku ini dengan AN masih membutuhkan penelitian lebih lanjut.

Pemerintah negara bagian Texas di Amerika Serikat telah melakukan skrining AN pada anak sekolah untuk mendeteksi anak yang memiliki risiko tinggi menderita diabetes tipe $2 .^{2}$ Negara bagian lain juga sedang mempertimbangkan untuk melakukan skrining yang sama. Skrining ini dilakukan bersamaan dengan skrining penglihatan, pendengaran, dan deformitas spinal pada anak. Melihat hal tersebut, dikembangkan suatu alur skrining AN seperti tertera pada Gambar 3. ${ }^{12}$

Pemeriksaan dasar AN pada pasien dewasa perlu dilakukan untuk melihat adanya kemungkinan terjadi keganasan. Pemeriksan penunjang yang lain adalah skrining terhadap adanya diabetes mellitus melalui tes toleransi glukosa atau pengukuran kadar hemoglobin terglikosilasi (HbA1c). Pemeriksaan kadar insulin plasma dilakukan untuk mengetahui adanya resistensi insulin. Kadar insulin plasma akan meningkat pada pasien dengan resistensi insulin. ${ }^{3}$

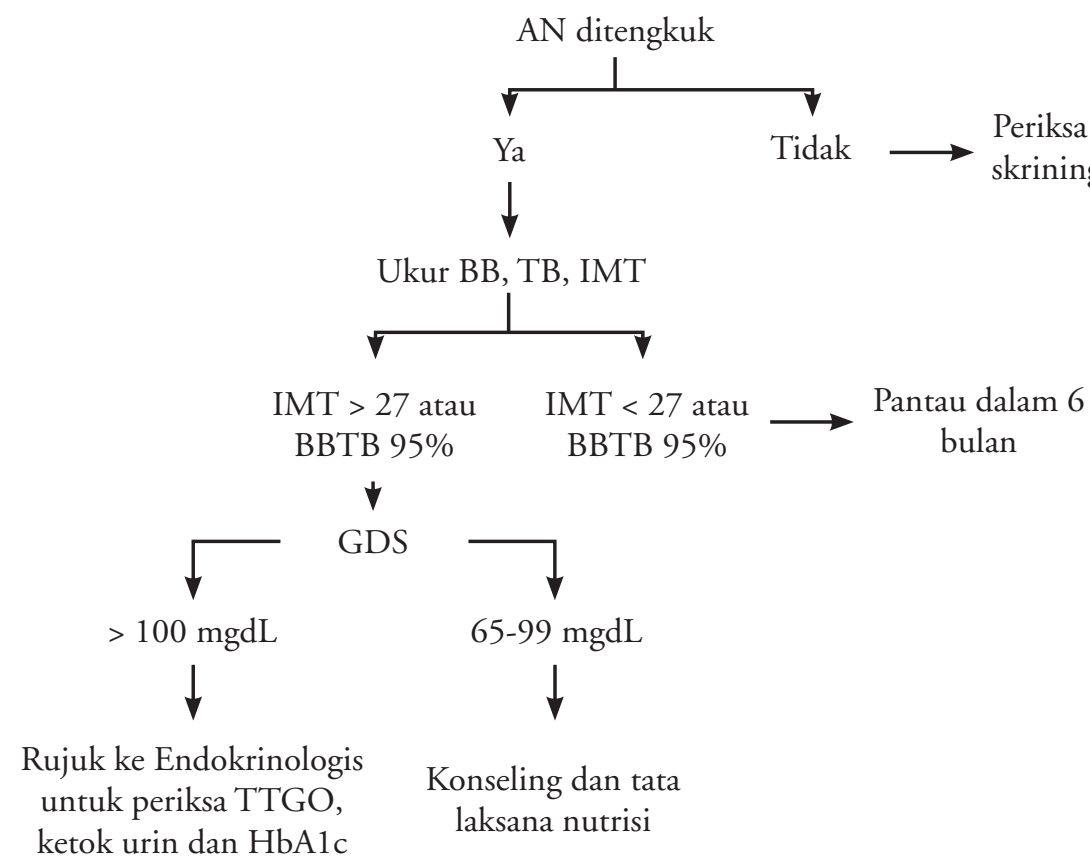

Gambar 3. Alur skrining acanthosis nigricans ${ }^{12}$ 
Jose RL Batubara: Acanthosis nigricans dan hubungannya dengan resistensi insulin pada anak dan remaja

\section{Terapi}

Tujuan terapi pada AN adalah untuk mengkoreksi penyakit yang mendasarinya. Terapi lesi hanya untuk tujuan kosmetik saja. Koreksi hiperinsulinemia dapat mengurangi derajat lesi hiperkeratosis, seperti halnya penurunan berat badan pada AN yang berhubungan dengan obesitas juga dapat mengurangi lesi dermatosis tersebut. Tidak ada terapi pilihan untuk AN. Terapi topikal yang telah diketahui efektif adalah keratolitik (misalnya tretinoin topikal). Pengobatan oral yang cukup efektif adalah isotretinin, metformin, dan minyak ikan. Ciproheptadin telah digunakan untuk terapi AN maligna karena dapat menghambat pelepasan produk tumor. ${ }^{3,11}$

\section{Edukasi dan prognosis}

Komplikasi AN bervariasi bergantung pada etiologi AN. Awitan AN yang timbulnya pada masa kanakkanak bisanya bersifat benigna. Sedangkan AN yang timbul pada usia dewasa lebih menakutkan karena harus dipikirkan kemungkinan adanya keganasan, meskipun sebagian besar AN yang awitannya pada dewasa adalah AN benigna dan berhubungan dengan resistensi insulin. ${ }^{3}$ Pasien harus diberikan informasi bahwa acanthosis nigricans bukan semata-mata kelainan kulit saja, tetapi merupakan salah satu tanda penyakit lain yang mendasari. Jika AN disebabkan oleh resistensi insulin maka tata laksana kelainan metabolik akan menyebabkan perbaikan lesi kulit. Perubahan diet dan penurunan berat badan dapat menyebabkan regresi lesi kulit secara sempurna. Prognosis pasien dengan AN maligna biasanya buruk. Angka rerata survival pada pasien ini kurang lebih dua tahun. ${ }^{3}$

\section{Kesimpulan}

Acanthosis nigricans tidak hanya dianggap sebagai kelainan kulit saja, tetapi dipandang sebagai petanda adanya penyakit lain yang mendasari, salah satunya adalah resistensi insulin. Oleh karena itu skrining AN pada anak-anak dan remaja, terutama di layanan primer, dapat menjadi sarana untuk mendeteksi adanya resistensi insulin lebih dini, bahkan sebelum diagnosis diabetes mellitus ditegakkan. Hal ini dapat memberi kesempatan kepada dokter dan pasien untuk mengusahakan intervensi berupa perubahan gaya hidup.

\section{Daftar pustaka}

1. Kobaissi HA, Weigensberg MJ, Ball gDC, Cruz ML, Shaibi GQ, Goran ML. Relation between acanthosis nigricans and insulin sensitivity in overweight hispanic children at risk for type 2 diabetes. Diabetes Care 2004:27:1412-6.

2. Acanthosis nigricans and insulin resistance. Didapat dari URL:http//www.tdh.state.tx.us/phpep/. Diakses tanggal 10 April 2007.

3. Levine N. Acanthosis nigricans. Didapat dari: URL:http// www.emedicine.com. Didapat tanggal 25 Maret 2007.

4. Saadi H, Lestringant GG, Nyomba BL, Bener A. Association of acanthosis nigricans with risk of diabetes and insulin resistance. Annals of Saudi Medicine 2000;20:69-71.

5. Eberting CLD, Javor E, Gorden P, Turner ML, Cowen EW. Insulin resistance, acanthosis nigricans, and hypertriglyceridemia. J Am Acad Dermatol 2005;52:341-4

6. Ten S, Maclaren N.Insulin resistance syndrome in children. J Clin Endocrinol Metab 2004;89:2526-39.

7. Araujo LMB, Porto MV, Netto EM, Ursich MJ. Association of acanthosis nigricans with race and metabolic disturbances in obese woman. Braz J Med Biol Research 2002;35:59-64.

8. Grandhe NP, Bhasali A, Dogra S, Kumar B. Acanthosis nigricans: relation with type 2 diabetes mellitus, anthropometric variables, and body mass in Indians. Postgrad Med J 2005;81:541-4.

9. Elmer KB, George RM. Acanthosis nigricans. Am Fam Physician 63(12):2385-90

10. Burke JP, Hale DE, Hazuda HP, Stern MP. A quantitative scale of acanthosis nigricans. Diabetes Care 1999;22:1655-9.

11. Ersoy-Evans S, Sahin S, Mancini AJ, Paller AS, Guitart J. The acanthosis nigricans form of epidermal nevus. J Am Acad Dermatol 2006;55:696-8.

12. Higgins SP, Freemark M, Prose NS. Acanthosis nigricans: a practical approach to evaluation and management. Dermatology Online Journal 2008;14(9):2. Available from URL: http://dermatology.cdlib.org/149/reviews/ acanthosisnigricans/higgins.html.

13. Kong AS, Williams RL, Robert R, Sandoval VU, Cardinali G, Weller NF, dkk. Acanthosis nigricans: high prevalence and association with diabetes in a practicebased research network consortium - a PRImary care Multi-Ethnic Network (PRIME Net) Study. The Journal of the American Board of Family Medicine 2010; 23: 
476-85. Ddidapat dari URL: http://www.jabfp.com/cgi/ content/full/23/4/476.

14. Kong AS, Williams RL, Smith M, Sussman AL, Skipper B, Hsi AC, dkk. Acanthosis nigricans and diabetes risk factors: prevalence in young persons seen in Southwestern US primary care practices. Ann Fam Med 20075:202-8.

15. Hardin DS. Screening for type 2 diabetes in children with acanthosis nigricans. Didapat dari URL:http//www. tde.sagepub.com. Diakses tanggal 10 April 2007.

16. Stoddart ML, Blevins KS, Wang W, Lee ET, Blackett PR.
Association of acanthosis nigricans with hyperinsulinemia compared with other selected risk factors for type 2 diabetes in Cherokee Indians. Diabetes Care 2002:1009-14.

17. Fukhusima N, Matsura N, Nohara Y, Fujita H, Endo M, Abe K, dkk. A case of insulin resistance associated with acanthosis nigricans. Tohoku J Exp Med 1984;144:12938.

18. Stuart CA, Smith MM, Gilkison CR, Shaheb S, Stahn RM. Acanthosis nigricans among native americans: an indicator of high diabetes risk. Am J Public Health 1994;84:1839-42. 